\title{
Impact of Critical Energy Facilities on the Components of the Environment
}

\author{
Elena P. Maysyuk \\ Melentiev Energy Systems \\ Institute of Siberian Branch of \\ the Russian Academy of \\ Sciences \\ Irkutsk, Russia \\ maysyuk@isem.irk.ru
}

\author{
Irina Yu. Ivanova \\ Melentiev Energy Systems \\ Institute of Siberian Branch of \\ the Russian Academy of \\ Sciences \\ Irkutsk, Russia \\ nord@isem.irk.ru
}

\author{
Alexandr K. Izhbuldin \\ Melentiev Energy Systems \\ Institute of Siberian Branch of \\ the Russian Academy of \\ Sciences \\ Irkutsk, Russia \\ izhbuldin@isem.irk.ru
}

\begin{abstract}
The study of the energy impact on the environment components and the assessment of the appropriateness of the environmental protection measures are primarily associated with a quantitative assessment of the scale of the impact produced by operation of energy facilities. The information and analytical system developing for assessing the impact of energy facilities on the environment components includes a database with a list of energy sources indicators, characteristics of the fuel used, parameters of environmental protection measures, and technologies. One of the challenges is how to assess the impact of energy facilities on the living conditions of the population and the natural environment of the region, and what indicators can be used to describe this impact.
\end{abstract}

Keywords - energy sector, environment, ontologies, information-analytical system, typology of emissions, assess of impact

\section{INTRODUCTION}

Energy, as a critical infrastructure, is a complex, diversified and multi-object system, including the extraction and transport of energy resources, the production of final products (electricity and heat) and their transmission to the consumer.

The operation of energy facilities affects all components of the environment. Energy facilities burning fossil fuel emit pollutants into the atmosphere, flush (drilling) water goes to the hydrosphere during extraction of fuel and energy resources, heated partially clean water enters the hydrosphere due to energy production, and changes the hydrobiological and chemical composition of waters. Impact on the soil is associated with disturbed landscapes and a significant amount of waste (during fuel extraction and energy generation), including the allocation of large areas for the waste disposal. In addition, energy production and transmission are associated with noise, thermal, and electromagnetic effects on the environment.

The study of the environmental impact caused by energy and the assessment of feasibility of applying environmental protection measures are primarily associated with a quantitative assessment of scale of the environmental impact caused by the energy facility operation, i.e. the determination of pollutant emissions/discharges; amount of waste generation; and the resulting level of air, water and soil pollution [1, 2]. In general, the greatest environmental impact of energy facilities is made on the atmosphere that receives a significant amount of harmful substances that can spread over long distances and areas, precipitate on water surfaces and soil. In this regard, the main focus in the study into the energy effect is presented in terms of air pollutant emissions.

To assess the impact of energy facilities on the components of the environment, an informationanalytical system is being developed. Its structure is given in [2]. The information part of the system is filled with indicators characterizing the operation of energy facilities, the characteristics of the qualitative composition of the fuel used to produce the end product (electricity and/or heat), and the parameters of environmental protection technologies. To identify the main factors affecting the level of impact caused by operating power facilities, we proposed the use of the analytical part of the system. In order to fill the information-analytical system with indicators and relationships, it was necessary to clarify not only the terms and definitions but also the interactions among all characteristics and indicators.

\section{RESEARCH METHODOLOGY}

In general, the scheme of the research into the impact of the energy sector on the environment components can be represented by three main stages: assessment of emissions, formation and assessment of pollution level, and analysis of changes in the environment (Fig. 1).

Changes in the natural composition of the environment components (atmosphere, water bodies, etc.) occur primarily due to the input of pollutants: emissions, discharges, waste. Therefore, the first stage of research involves estimating how much foreign matter enters each component of the natural environment.

Currently, there are developed and approved methods designed to estimate the amount of pollutant emissions from boilers of different capacities [3-7]. As 
a rule, the emissions are determined for three main substances: particulate matter $(\mathrm{Mpm})$, sulfur dioxides (Ms), and nitrogen oxides (Mn). However, it must be borne in mind that for different power plants and different types of fuel the structure of emissions may vary.

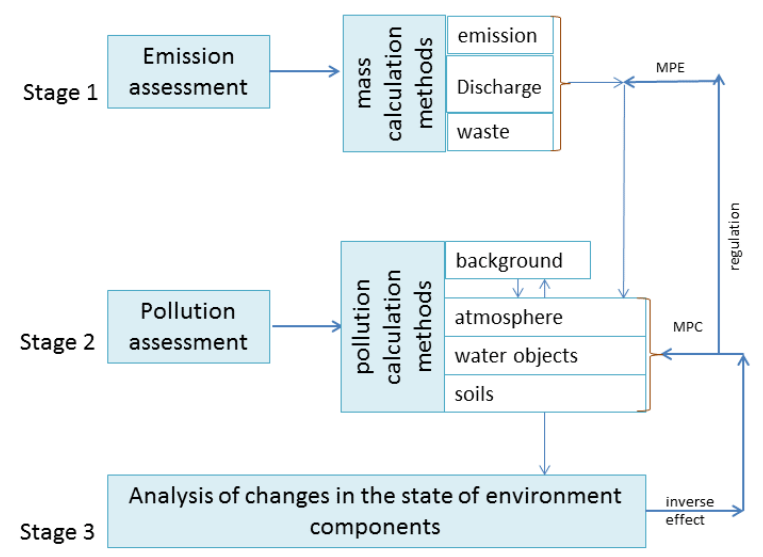

Fig. 1. General scheme of research

Another quantitative estimation is the calculation of the mass of waste from fossil fuels combustion. Currently, there are no officially approved methods for calculating the amount of production and consumption waste. However, there are various methods for calculating the standard amount of production and consumption waste, for example, the so-called normative method [8]. Based on the generalization of the existing methods for the quantitative assessment of the ash and slag waste (MWS) from energy facilities, it seems appropriate to apply the calculation method based on the mass balance [9].

The next (second) stage of the research involves the estimation of pollution levels in each natural environment component as a result of pollutant emission. This requires a different set of indicators characterizing the background state of the natural environment components to take into account emissions.

The background state of the environment components is described by physiographic and climatic characteristics. Physiographic characteristics include the location, size/extension of the territory, resources, population, etc. Natural and climatic characteristics describe the state of the territory's climate and include meteorological indicators (speed, direction and frequency of wind, temperature, etc.), inversion states, hydrological information, etc. All these characteristics are closely related.

The calculation of pollution levels provides the concentration of impurities in the natural environment component, which can be caused by a source of emissions in specific environmental conditions. The concentrations are calculated using the Guidelines for calculating the dispersion of harmful substances in the atmosphere and the Method of calculating the concentrations of harmful substances in the emissions from enterprises in the atmospheric air [10-11].
The third stage of the research on the environmental impact of energy facilities includes an analysis of possible changes that may deteriorate the quality of the environment component itself and quality of other components, thus influencing the social and economic environment, i.e. human. In fact, there occurs an inverse effect whose description and assessment require a different set of indicators related to the concentration of harmful substances permissible for vital activity in all components of the natural environment. In general, the concentration generated by emissions and climatic conditions is used to develop regulatory mechanisms, in particular to determine the standards for the maximum permissible emissions (MPE).

\section{SYSTEMATIZATION OF INFORMATION FOR THE RESEARCH}

The information necessary for research can be systematized into several groups, because the assessment of the anthropogenic impact of energy facilities depends on many factors. First of all, these are general information about all energy sources operating in the territory in question: the composition and type of equipment, installed capacity, electricity and heat production, type and fuel consumption. Energy sources can be divided into groups of objects burning various types of fossil fuel characteristic of the territory. The qualitative composition and technical characteristics of the fuel burned at energy facilities have a considerable impact on the amount of emissions to the components of the environment.

Apart from the main technical and production indicators of energy sources, the assessment of the environmental impact requires detailed information on the method of burning fuel, burner design, type of furnace and cleaning equipment, type of slag removal, and chimney height. The cleaning equipment characteristics, including the collection efficiency, are also needed.

\section{A. Ontological research}

A number of ontologies are built to determine the composition and accessibility of information which is necessary to identify the influence of energy on the natural environment components. These are: the metaontology of interrelations between energy and geoecology, the ontology of the production process in energy, the ontology of energy production and conversion phases [1].

Thus, the metaontology of energy and environment components illustrates the general relations between these two basic concepts (Fig. 2). In the future, it is planned to clarify the concepts and stratify the ontologies for a greater degree of detail of each layer.

In general, the ontologies are used to form databases and integrate information for further processing, given model calculations using automated tools. The information organized in this way makes it possible to provide the information-analytical system with data to assess the impact of energy on the components of the environment. 


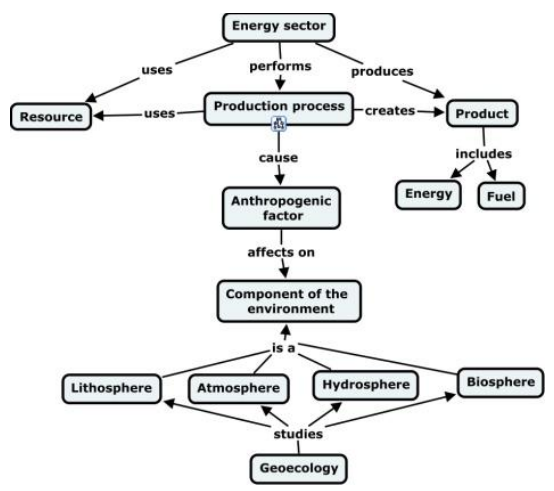

Fig. 2. Metaontology of interrelations between energy and geoecology

\section{B. Typology of emissions in the components of the environment}

Typology (Greek "tipos" - imprint, form, pattern and "logos" - word, teaching) is commonly understood as a method of scientific cognition, aimed at dividing some studied set of objects into ordered and systematized groups with certain properties using an idealized model or type [12]. In other words, typology is a result of a complex and multi-level reconstruction of the studied set of components (objects), which can be performed according to different criteria simultaneously.

In fact, typology can be a multi-level procedure, when the homogeneity (typology) revealed at the first level is used to find the homogeneity of the second level, etc. Normally, the typologies obtained are incomplete, i.e. they do not cover the entire set of objects studied. Therefore, any typology has some limit, beyond which it cannot be extended, but it is often possible to propose another type of typology next to it, in the same subject domain [13].

In this study, the typology of the first stage of research aims to systematize the same type of indicators used to calculate the emissions, and the amount of waste under various conditions. In this case, the conditions are the methods of fuel combustion, the capabilities of trapping harmful substances before they enter the environment (Table I). The indicators used in the calculations are described in more detail in [9].

TABLE I. TYPOLOGY OF THE MAIN INDICATORS REQUIRED FOR CALCULATION OF EMISSIONS AND WASTE FROM ENERGY FACILITIES

\begin{tabular}{|c|c|c|c|c|c|c|c|c|c|c|}
\hline \multirow{3}{*}{$\begin{array}{c}\text { Emi } \\
\text { s- } \\
\text { sion }\end{array}$} & \multicolumn{10}{|c|}{ Some of the main characteristics of } \\
\hline & \multicolumn{4}{|c|}{ Fuel } & \multicolumn{3}{|c|}{$\begin{array}{c}\text { Combustion } \\
\text { process }\end{array}$} & \multicolumn{3}{|c|}{$\begin{array}{c}\text { Cleaning } \\
\text { equipment }\end{array}$} \\
\hline & $\begin{array}{c}V, \\
\text { t/year }\end{array}$ & $\underset{\%}{A p}$ & $\begin{array}{l}S p \\
\%\end{array}$ & $\begin{array}{c}Q p n \\
k J / \\
k g \\
\end{array}$ & $\begin{array}{l}q_{3} \\
\%\end{array}$ & $\begin{array}{l}q_{4} \\
\%\end{array}$ & $\begin{array}{l}A_{f l y} \\
n / d\end{array}$ & $\begin{array}{l}\eta_{z} \\
\%\end{array}$ & $\begin{array}{l}\eta s_{3} \\
\%\end{array}$ & $\begin{array}{l}\eta_{1} \\
\%\end{array}$ \\
\hline \multicolumn{11}{|c|}{ Emission } \\
\hline $\mathrm{M}_{\mathrm{pm}}$ & + & + & + & + & + & + & + & + & - & - \\
\hline Ms & + & + & + & + & - & - & - & - & + & - \\
\hline $\mathrm{Mn}$ & + & + & + & + & + & + & - & - & - & + \\
\hline \multicolumn{11}{|c|}{ Waste } \\
\hline $\mathrm{M}_{\mathrm{asw}}$ & + & + & - & + & - & + & + & + & - & - \\
\hline
\end{tabular}

The main indicators for typology and further calculation of pollution levels in the second stage of the research, are the indicators of climatic characteristics of the territory, technical and technological conditions of emission release and physiographic data on the territories where the emission sources are located. To describe and assess the pollution, (Table II) lists the main indicators used to determine the maximum concentration of a pollutant and the distance at which this concentration is formed.

The above list of indicators for calculating the level of pollution of the environment components requires a typology regarding the amount of emission and its composition to assess the density of pollution deposited on the earth's surface and its impact on changes in the state of the environment components and humans.

TABLE II. TYPOLOGY OF THE MAIN INDICATORS REQUIRED FOR CALCULATION OF EMISSIONS AND WASTE FROM ENERGY FACILITIES

\begin{tabular}{|c|c|c|c|c|}
\hline \multirow{2}{*}{$\begin{array}{l}\text { Character } \\
\text { istic }\end{array}$} & \multirow[t]{2}{*}{ Index } & \multirow{2}{*}{$\begin{array}{l}\text { Measur } \\
\text { ement } \\
\text { units }\end{array}$} & \multicolumn{2}{|c|}{$\begin{array}{c}\text { Pollution of } \\
\text { the natural } \\
\text { environment } \\
\text { component }\end{array}$} \\
\hline & & & $\begin{array}{c}\text { Max } \\
\text { concent } \\
\text { ration } \\
\end{array}$ & $\begin{array}{c}\text { Max } \\
\text { dista } \\
\text { nce }\end{array}$ \\
\hline \multirow{3}{*}{ Climatic } & Wind speed & $\mathrm{m} / \mathrm{sec}$ & + & - \\
\hline & $\begin{array}{ll}\text { Wind } & \text { direction } \\
\text { frequency } & \end{array}$ & $\%$ & + & - \\
\hline & $\begin{array}{l}\text { Ambient air } \\
\text { temperature }\end{array}$ & ${ }^{\circ} \mathrm{C}$ & + & + \\
\hline \multirow{6}{*}{$\begin{array}{l}\text { Emission } \\
\text { conditions }\end{array}$} & $\begin{array}{l}\text { Pollutant emission } \\
\text { (mass of emission, } \\
\text { mass of waste) }\end{array}$ & $\begin{array}{c}\mathrm{g} / \mathrm{sec} \\
\text { (t/year) }\end{array}$ & + & - \\
\hline & $\begin{array}{l}\text { Height of emission } \\
\text { source }\end{array}$ & M & + & + \\
\hline & $\begin{array}{l}\text { Temperature of flue } \\
\text { gases }\end{array}$ & ${ }^{\circ} \mathrm{C}$ & + & + \\
\hline & $\begin{array}{l}\text { Speed of gas-air } \\
\text { mixture release }\end{array}$ & $\mathrm{m} / \mathrm{sec}$ & + & + \\
\hline & $\begin{array}{l}\text { Volume of the gas- } \\
\text { air mixture release }\end{array}$ & $\mathrm{m}^{3} / \mathrm{sec}$ & + & - \\
\hline & $\begin{array}{l}\text { Coefficient of } \\
\text { sedimentation } \\
\text { velocity }\end{array}$ & $n-d$ & & + \\
\hline \multirow{2}{*}{$\begin{array}{l}\text { Physiogra } \\
\text { phic }\end{array}$} & $\begin{array}{l}\text { Coefficient of } \\
\text { surface roughness }\end{array}$ & $n-d$ & + & + \\
\hline & $\begin{array}{l}\text { Climatic coefficient } \\
\text { of a territory }\end{array}$ & $n-d$ & + & - \\
\hline
\end{tabular}

\section{THE CRITICAL IMPORTANCE OF ENERGY FACILITIES WITH REGARD TO THEIR INFLUENCE ON THE NATURAL ENVIRONMENT COMPONENTS}

One of the difficulties encountered in the research was the determination of criteria for the critical importance of energy facilities in terms of their influence on the components of the environment.

Traditionally, the concept of critical importance of energy facilities is associated with the impact on the energy security of an area. Energy facilities as part of the energy sector affect the security of the sector as a whole. The extent of the effect is measured by the indicator and its boundary value. As a result, a 
conclusion is made about whether or not there are threats to a stable energy supply to the consumer [14].

From the energy security perspective, it is customary to consider various types of threats: a danger of environmentally-unfriendly operation, a risk of an emergency at a power facility or in the energy infrastructure (networks, communications, etc.). In this case, the economy and the population will be left without electricity and heat, and the emergency development will cause damage mainly to the nearby population.

A large number of external conditions influence the energy security indicators. One of the main factors is the territorial level of the security. The same facility can be critical for one level and not at all critical for another.

At the same time, energy facilities are critically important from an environmental viewpoint. Entering the environment, the pollutants from energy facilities in the form of emissions, discharges and industrial waste are transformed into the pollution that changes the components of the environment. In turn, the modified components of the environment affect humans.

In the context of environmental security, the operation of power facilities causes damage to public health and does harm to living organisms due to the emission of harmful substances and the formation of pollution in the components of the environment, both close to the power facility and at a distance. As showed above, pollution is formed depending on certain climatic conditions, mass emission, height of chimneys and the location of energy facilities.

Thus, in terms of the energy security, critical facilities affect the consumer by changing the characteristics of technical systems that are part of the energy sector, while in terms of the environmental impact, critical facilities affect the components of the environment and the quality of life of the population.

The critical energy facilities should be identified in the initial stage of research and their set will vary depending on the territorial level.

\section{CONCLUSION}

An information-analytical system is under development to study the impact of the energy sector on the environment components, to select and use various environmental protection measures. To furnish the system with necessary data and provide its operation, it is necessary to quantitatively assess the influence of energy facilities on the components of the natural environment. The results of the assessment are emissions/discharges of pollutants, and the amount of waste that form the level of pollution of each environment component.

In this context, the relationships between the energy sector and environment components have been considered through the ontological research, which makes it possible to systematize and order a large volume of indicators, and clarify the relationships between them

A typology of pollutant emissions from energy facilities was carried out depending on the composition and the type of fuel burned. A list of influencing characteristics and indicators was made up. An attempt was made to form a list of indicators needed to calculate the level of pollution.

The analytical part of the information-analytical system designed to assess the environmental impact of the energy sector required clarifications of the terms and definitions, and the relationships within the entire set of characteristics and indicators. One of the difficulties encountered in the research was the determination of criteria for the critical importance of energy facilities in terms of their impact on the environmental components.

\section{ACKNOWLEDGMENT}

The research is supported by the RFBR (Project № 18-57-81001).

\section{REFERENCES}

[1] L.V. Massel, "Ontological aspects of investigation energy and geoecology relationship" / Massel L.V., Ivanova I.U., Vorozhtsova T.N., Maysuyk E.P., Izhbuldin A.K., Zorina T.G., Barsegyan A.R. // Ontology of design. - 2018. - V. 8, №4(30). - Pp.550-561. [Ontologicheskie aspekty issledovaniya vzaimovliyaniya energetiki i geoekologii, Ontologiya proektirovaniya, 2018, V.8, №4(30), Pp. 550-561] (In Russian)

[2] E. Maysyuk, I. Ivanova, "Environmental protection technologies as an aspect of research into critical infrastructures" / Proceedings of the V International workshop "Critical infrastructures: Contingency Management, Intelligent, Agent-based, Cloud Computing and Cyber security" (IWCI 2018), 2018. - Pp. 142-146.

[3] Collection of methods for calculating emissions of pollutants into the atmosphere by various industries. - Leningrad, Goskomgidromet, 1986. - p. 1-27. [Sbornik metodik po raschetu vybrosov $\mathrm{v}$ atmosferu zagryaznyayushchih veshchestv ot razlichnyh proizvodstv, Leningrad, Goskomgidromet, 1986, p. 1-27] (In Russian)

[4] Methods for determining the gross emissions of pollutants into the atmosphere from boilers of thermal power plants. RD 34.02.305-98 / VTI. - Moscow, 1998. [Metodika opredeleniya valovyh vybrosov zagryaznyayushchih veshchestv $\mathrm{v}$ atmosferu ot kotel'nyh ustanovok TES, VTI, Moskva, 1998] (In Russian)

[5] Methodology for determining pollutant emissions when fuel is burnt in boilers with a capacity of below 30 tons of steam per hour or below $20 \mathrm{Gcal}$ per hour. M.: State Committee for Environmental Protection of the Russian Federation (with the participation of the company Integral, St. Petersburg), 1999. 53 p. [Metodika opredeleniya vybrosov zagryaznyayushchih veshchestv $\mathrm{v}$ atmosferu pri szhiganii topliva $\mathrm{v}$ kotlah proizvoditel'nost'yu menee 30 tonn para $\mathrm{v}$ chas ili menee 20 Gkal v chas, Gosudarstvennyj komitet po ohrane okruzhayushchej sredy Rossijskoj Federacii, 1999, p. 53] (In Russian)

[6] Methodological letter of the Research Institute "Atmosphere" No. 335/33-07 dated May 17, 2000 "On the calculation of emissions of harmful substances into the atmosphere according to the "Method for determining pollutant emissions when fuel is burned in boilers with a capacity of below 30 tons of steam per hour or below 20 Gcal per hour "(Moscaw, 1999). St. Petersburg: Research Institute “Atmosphere”, 2000. $20 \mathrm{p}$. 
[7] The method of calculating pollutant emissions from stationary diesel plants. / St. Petersburg: Research Institute "Atmosphere", 2001, 18 p. [Metodika rascheta vybrosov zagryaznyayushchih veshchestv $\mathrm{v}$ atmosferu ot stacionarnyh dizel'nyh ustanovok, nauchno issledovatel'skij institut Atmosfera, Sankt-Peterburg, 2001, p. 18] (In Russian)

[8] On approval of individual methodological documents in the field of environmental protection. Order of the Ministry of Environmental Protection of the Republic of Kazakhstan of April 18, 2008 No. 100-p. On-line. Available: http://new.ecogosfond.kz/wp-content/uploads/100-ves.pdf

[9] E.P. Maysyuk, I.Yu. Ivanova, Analysis of existing methods for assessing the environmental impact of energy facilities // Information and Mathematical Technologies in Science and Management. 2018. No. 4 (12). Pp. 113-127. [Analiz sushchestvuyushchih metodov ocenki vozdejstviya energeticheskih ob"ektov na okruzhayushchuyu sredu, Informacionnye $\mathrm{i}$ matematicheskie tekhnologii $\mathrm{v}$ nauke $\mathrm{i}$ upravlenii, 2018, No. 4 (12), Pp. 113-127] (In Russian)

[10] Guidelines for calculating the dispersion of harmful substances (dust, sulfur dioxide) contained in industrial emissions in the atmosphere / $\mathrm{CH}$ 369-74. Moscow: Gidrometeoizdat, 1975. [Ukazaniya po raschetu rasseivaniya v atmosfere vrednyh veshchestv, soderzhashchihsya v vybrosah predpriyatij, Moskva, Gidrometeoizdat, 1975] (In Russian)

[11] The method of calculating concentrations of harmful substances in the emissions from enterprises. All-Union Standard Document-86. - Leningrad: Goskomgidromet, 1987. [Metodika rascheta koncentracij $\mathrm{v}$ atmosfernom vozduhe vrednyh veshchestv soderzhashchihsya v vybrosah predpriyatij, Leningrad, Goskomgidromet, 1987] (In Russian)

[12] Typology. Philosophical dictionary. On-line. Available: https://dic.academic.ru/dic.nsf/dic_new_philosophy/1223

[13] The newest philosophical dictionary. - Minsk: Book House. A. A. Gritsanov. 1999 [Novejshij filosofskij slovar', Minsk, Knizhnyj Dom, 1999] (In Russian)

[14] Energy security of Russia: problems and solutions / N.I. Pyatkova [and others]; ed. by N.I. Voropai, M.B. Cheltsov; Melentiev Energy Systems Institute SB RAS. - Novosibirsk: Publishing House of the SB RAS, 2011. - 198 p. 